\title{
Release Ruchell Cinque Magee: Sole Survivor of the August 7, 1970 Courthouse Slave Rebellion! Ruchell Cinque Magee with Kiilu Nyasha
}

Shortly after August 7, 1970, photos of what's become known as the "Courthouse Slave Rebellion" hit the front pages of the nation's dailies showing four Black men emerging from the Marin County Court with guns and hostages, including a judge, prosecutor and three jurors, provoking panic in some and pride in others.

In the historical context of aggressive, official violence against Black prisoners, Magee appeared in court that fateful morning to testify for fellow prisoner, James McClain, defending himself against the charge of assaulting a guard in the wake of the murder by racist San Quentin guards of Fred Billingsley, beaten and tear-

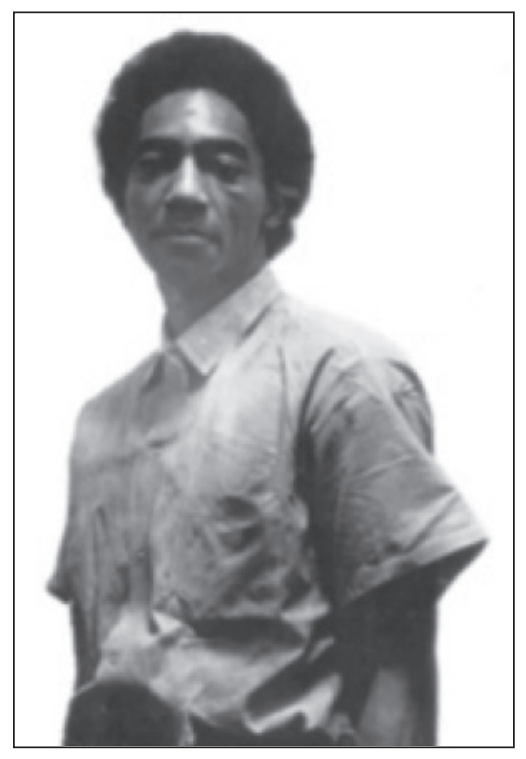

Ruchell Cinque Magee gassed to death in his cell earlier that year.

Magee was on the witness stand when Jonathan Jackson (age 17), younger sibling of Soledad Brother George Lester Jackson, burst into the court room "courage in one hand, assault rifle in the other", and took charge. The plan was to release McClain and William Christmas, use hostages to make it to a radio station to expose the virulent prison conditions, and demand the immediate release of the three Soledad Brothers facing capital charges in the death of a prison guard following the murder of three Black prisoners at Soledad State Prison. The Soledad Brothers were ultimately acquitted, Jackson posthumously.

What the rebels failed to anticipate was the total disregard for human life of the San Quentin guards who arrived in time to riddle the van with bullets before it could leave the parking lot.

In this barrage of gunfire, Christmas, Jackson, McClain and Judge Harold

Haley were killed, the prosecutor was seriously wounded (remains paralyzed), a juror slightly injured, and Magee was critically wounded and lay unconscious. 
Professor Angela Y. Davis was captured and imprisoned for having purchased the guns (legally) and was later acquitted of all charges in a separate trial.

The following statements were written by Ruchell Magee (with some editing by Kiilu Nyasha):

I was charged with kidnap to rob for $\$ 10$ in the Los Angeles prosecution which commenced March 1963. A life sentence from LA still goes on 42 years later. The Board turned seven years to life, into life without possibility of parole. I was also charged with kidnap out of Marin County Courthouse, August 7, 1970, in addition to murder and conspiracy charges. I was acquitted of the more serious kidnap charge (PC 209), although the jury verdict was not honored, but convicted of the simple kidnap charge (PC 207). You will find the murder and conspiracy charges were dismissed.

In an affidavit signed by the elected Jury Foreman in Magee's trial (\#68668, Superior Court of San Francisco County), Bernard J. Suares stated, on August 6, 2001:

That at the end of the jury's deliberations (commenced on March 26, 1973 and terminated April 3, 1973) all 12 jurors found Mr. Magee not guilty of violating P.C. 209 (kidnapping for the purpose of extortion).... I have appealed to the Court and have presented proof of acquittal, which is being concealed by the court in violation of the Rico Act and Mr. Magee's Constitutional right to a fair trial. I have been ignored for more than 23 years and demand that I be heard in a court of law.... I declare under penalty of perjury the foregoing is true and correct to the best of my knowledge and belief.

In a letter to Public Defender Richard Such, dated May 2, 1975, Juror David F. Smith stated:

The State presented no evidence to indicate that Mr. Magee knew in advance that an escape attempt would be made.... Most of the jurors thought that Magee was a person who felt strongly that he 
had been wrongfully imprisoned, who felt morally entitled to be free under the Constitution and the laws of the land ... who sensed a momentous possibility of immediate freedom and who grasped at it.

Citing failure to comply with Penal Code 1170.2 (Determinate Sentence Law) requiring the Board of Prison Terms to set a release date for prisoners not doing life without the possibility of parole, on May 10, 2000, Mr. Albert M. Leddy released a declaration, which read in part:

I was attorney at law, currently retired... Between 1983 to 1992, I served as a commissioner and then as Chairman for the Board of Prison Terms (BPT).... At one point I became concerned enough about the 'no parole policy' that I wrote a nine page brief about how we were not complying with the laws. I gave a copy to each Board member, pointing out that we could be sued. Such a noparole policy is contrary to Penal Code $\S 3041$ which requires that BPT shall normally set a parole date in most cases, unless the prisoner is shown to pose a threat to public safety....

It has been clear to me that there is a general conspiracy to prevent life prisoners from paroling, especially those whose offenses include murder... If you can deny a prisoner suitability solely on the basis of the crime, you can deny him forever. The crime won't change. The parole law is based on the idea that prisoners do change, and become no danger to public safety.

There is no rational explanation for the Board's conduct, which is in violation of Penal Code 1170.2 (Determinate Sentence Law). In fact, some prisoners held illegally have died inside unnoticed.

Moreover, do you recall the case of Dr. Bernard Fink? He was convicted of the torture murder of his wife who was decapitated, and did less than 15 years. There are many other cases of prisoners convicted of horrific crimes who came to prison after me and have been released. 
Magee poses no threat to the public if released. He is 66 years old, has no mental problems, doesn't use drugs, smoke or drink alcohol, or allow others to think for him. He believes he would be a mentor in the community to help young folks turn away from negative behaviors that lead to prison and senseless death.

In closing, I urge you to write to the Governor asking him to assign a special Board for compliance with PC 1170.2 (DSL) that would bring relief to countless prisoners suffering prolonged incarceration in prisons throughout California.

Forty-two years is enough! Free Ruchell Cinque Magee now! Free all political prisoners!

You may write directly to Ruchell at:

A92051

3C 02-127

Box 3471

Corcoran, CA 